\title{
DIAMOND EVALUATION OF THE PRAIRIE CREEK LAMPROITE PROVINCE, ARKANSAS, USA
}

\author{
Dennis Dunn, \\ University of Texas at Austin, USA
}

\section{REGIONAL GEOLOGY}

The Prairie Creek lamproite province consists of seven known diamondiferous lamproite vents within a belt that extends for $5 \mathrm{~km}$, in a northeasterly direction from the largest of the vents, Prairie Creek (Figure 1). The Prairie Creek lamproite has a K-Ar age of $\sim 106 \mathrm{Ma}$ (Gogineni and others, 1978). The northeast alignment is sub-parallel to the northeast-trending Reelfoot Rift located $\sim 100 \mathrm{~km}$ east of the intrusions. The lamproite province straddles the geologic and physiographic boundary between the Cenozoic Gulf Coastal Plain and the Paleozoic Ouachita Mountains. It is widely believed that the lamproite province lies near the southern margin of the North American craton which consists of 1.3 to $1.5 \mathrm{Ga}$ graniterhyolite terrane (Van Schmus and others, 1986).

Three previously unexplored Arkansas lamproites were delineated and evaluated during the 1980's. The three vents - Black Lick (10 hectares), Twin Knobs 2 (2 hectares) and Timberlands ( $<1$ hectare) -- were intruded into the Lower Cretaceous Trinity Group and are overlain unconformably by the Late Cretaceous Tokio Formation rocks. Lamproites consist of marginal sandy tuffs and fine-grained lapilli tuffs which appear to be transitional to, and intruded by, later coarser-grained lapilli tuffs and more massive autolithic breccias near specific loci within the vents. Some of the hypabyssal lamproite may have reached the surface as lava flows. The observed eruptive relationship is in good agreement with the idealized eruptive sequences of lamproites described by Mitchell and Bergman (1991).

\section{DIAMOND BULK TESTING}

Both the Black Lick and Twin Knobs 2 lamproites were bulk-tested utilizing trenches within pyroclastic rocks. The material was transported via covered truck to a recovery plant near Sloan, Colorado. The plant utilized a jaw crusher, scrubber, washer and various screens to produce a consistent feed into a heavy media circuit. The diamonds were recovered from the heavy media concentrate using both "SORTEX" and grease table technology for redundancy. Three macro diamonds in excess of $0.5 \mathrm{~mm}$ were recovered from the 155 tonnes of material from the Black Lick lamproite. The calculated diamond grade throughout the Black Lick lamproite was approximately 0.03 carats per 100 tonnes. Two additional macro diamonds in excess of $0.5 \mathrm{~mm}$ were recovered from the 105 tonnes of material from the Twin Knobs 2 lamproite (Figure 2). The calculated diamond grade throughout the Twin Knobs 2 lamproite was approximately 0.04 carats per 100 tonnes. The calculated average diamond content of both intrusions was an order of magnitude less that that observed at the Prairie Creek lamproite which yielded an average diamond grade of 0.57 carats per 100 tonnes (Morgan Worldwide Mining Consultants, 1997), and for the Twin Knobs 1 lamproite which yielded a grade of 0.17 carats per 100 tonnes (Waldman and others, 1987).

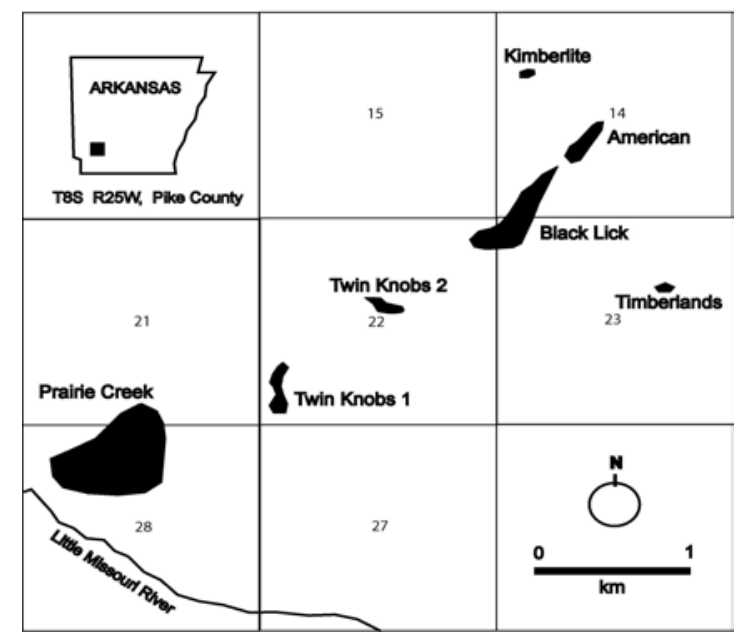

Figure 1: Location of known Prairie Creek lamproite vents.

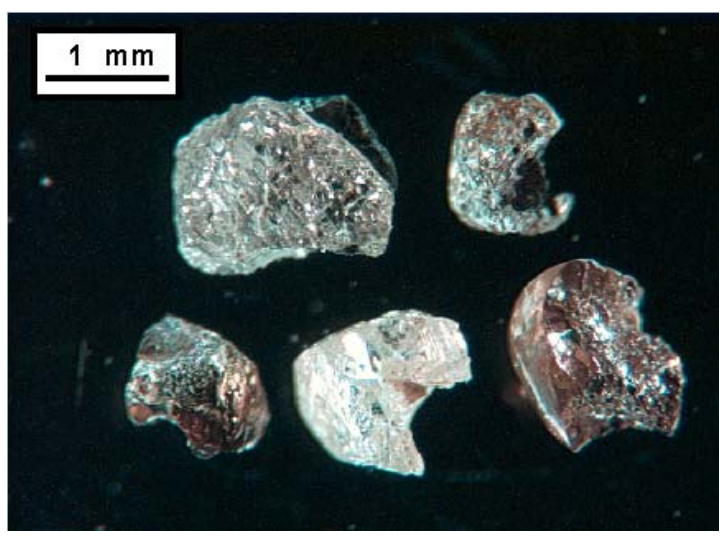

Figure 2: Diamonds recovered during bulk sampling evaluation. The top two diamonds are from Twin Knobs 2; the three lower diamonds are from Black Lick lamproite.

\section{$8^{\text {th }}$ International Kimberlite Conference Long Abstract}




\section{MINING HISTORY}

Diamonds were first discovered at the Prairie Creek lamproite in 1906, and commercial mining continued intermittently until 1931. A diamond evaluation program undertaken at the Prairie Creek vent by the Arkansas State Parks Commission in the 1990's resulted in mapping and diamond evaluation of four major rock types. The epiclastic rocks consist of medium-grained quartz sandstone and comprise about $5 \%$ of the surface area. The olivine lamproite is a very hard, dense, greenishblack olivine porphyry lamproite which comprises slightly less than half of the surface area. Evaluation of these rock types indicates they contain insignificant amounts of diamond. However, the fine-grained phlogopite-rich tuffs which comprise about $20 \%$ of the surface outcrop have an estimated diamond content of $\sim 0.11$ carat/100 tonnes. The coarse-grained olivine-rich tuffs comprise $\sim 30 \%$ of the surface outcrop and have an estimated diamond content of $\sim 1.1$ carat/100 tonnes.

\section{MODEL AND EROSION HISTORY}

The unique stratigraphic relationship in which the Arkansas lamproites were intruded allows accurate determination of the amount of lamproite erosion since Late Cretaceous time. The elevation of this erosion surface is $\sim 150$ meters above mean sea level. Extrapolation of this disconformity to the southwest reveals that the Prairie Creek vent within the Crater of Diamonds State Park was probably buried by the Tokio Formation during the Late Cretaceous Period. It was only exhumed by erosion in recent geologic time by the action of the Little Missouri River (Figure 3). The average elevation of the visitor search area at the Crater of Diamond State Park is just higher than 100 meters above sea level, and so the average thickness of the diamondiferous intrusion removed by erosion in recent geologic time is less than 50 meters (Dunn, 2002).

This erosion depth, the area of intrusion, and the approximate diamond grade of the removed rock yields an estimate of the total volume of original diamonds liberated by erosion. The density of in-situ weathered lamproite during the 1990's evaluation was found to be $\sim 1.65$ tonnes per cubic meter. The geologic mapping indicated about $20 \%$ of the surface area $(6.4$ hectares or 64,000 square meters) to be phlogopite-rich lamproite with an average diamond content of $0.11 \mathrm{cpht}$. Assuming a maximum erosion depth of 50 meters, the total eroded volume of phlogopite-rich tuffs is $3,200,000$ cubic meters or $\sim 5,280,000$ tonnes of material. If this material contained an average grade of $0.11 \mathrm{cpht}$, a total of $\sim 5,800$ carats of diamond would have been liberated. The same calculation for the olivine-rich pyroclastics that cover
$30 \%$ of the mapped vent yields 9.6 hectares of exposure or 96,000 square meters of olivine-rich pyroclastics. This number multiplied by a maximum erosion depth of 50 meters yields a total volume of $4,800,000$ cubic meters or $\sim 7,920,000$ tonnes. If this material contained an average grade of $1.1 \mathrm{cpht}$, a total of $\sim 87,000$ carats of diamond would have been liberated. All of the diamondiferous material eroded since exhumation of the deposit would yield an estimated 93,000 carats of diamond.

Chemical weathering is expected to predominate over physical transport of material in a low-relief sub-tropical environment such as southwestern Arkansas. This process permits the concentration of resistant minerals in surface soils. Theonen and others (1949) noted that "The greatest concentration of diamonds appears to have been found in the black ground capping the brecciated peridotite. This averaged about 2.5 feet thickness and yielded a diamond concentration of approximately 0.844 carat per cubic yard" ( $\sim 50 \mathrm{cpht})$.

Records of the early diamond production are sparse, with the most complete review of diamond production and grades that of Fuller (1931). He reported that mining operations were recovering $\sim 15 \mathrm{cpht}$ with an average stone size of 0.35 carats. Fuller suggested that at least two grades of ore were processed. The first ore type was rich in diamonds and yielded recovered diamond grades of $15 \mathrm{cpht}$ with actual total diamond contents possibly in excess of $30 \mathrm{cpht}$. The second reported ore grade encompassed over $50 \%$ of the material processed, and indicated an average recovered ore grade of approximately $0.5 \mathrm{cpht}$.

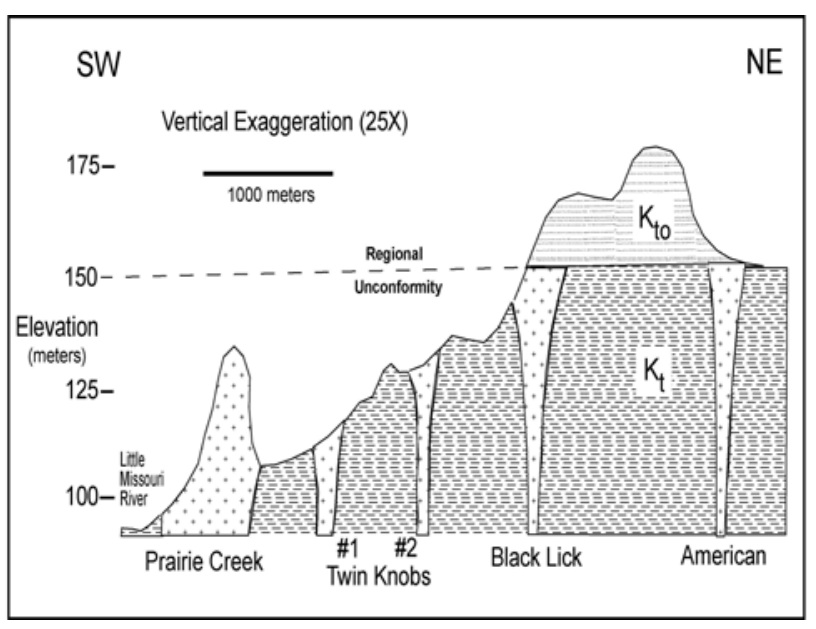

Figure 3: Erosion profile across the Arkansas lamproite province. Estimated level of erosion of the Prairie Creek lamproite below the regional unconformity is indicated. 
The U.S. Bureau of Mines evaluation during the 1940's consisted of 54 large diameter holes drilled from the surface, yielding $\sim 240$ cubic meters or 395 tonnes of material. Processing of this material yielded 32 stones weighing a total of 8.41 carats for an average grade of 2.1 cpht and an average size of 0.25 carats (Theonen and others, 1949). This ore grade is slightly higher than the Glenn Martin bulk test results where a large bulk sample from the consolidated mining properties produced about 246 carats from approximately 112,000 tonnes of material (St. Clair, 1956). The calculated ore grade during this evaluation is approximately $0.22 \mathrm{cpht}$.

Review of the Crater of Diamonds State Park mining history and the results of the 1990's evaluation suggest that two types of diamond resources were encountered at the Prairie Creek lamproite. The first ore type was relatively rich in diamonds with recovered ore grades in excess of $15 \mathrm{cpht}$. This material constituted the bulk of the material washed in the earliest mining operations. During the 1920's two ore grades can be distinguished. The higher-grade ore had grades comparable to those of earlier mined surface enrichments and was probably constituted from the same material. The lower grade ore processed appears to represent in-situ pyroclastic lamproite and yielded diamond contents averaging $<1.0$ cpht.

Later economic evaluations at the Prairie Creek vent specifically evaluated the in-situ lamproite, as the enriched surface material had been depleted. The U.S. Bureau of Mines test, which may have included some surface material, yielded average diamond contents of 2.1 cpht. Glenn Martin's large scale evaluation in 1948 yielded average grades of about $0.22 \mathrm{cpht}$, and the 1990's evaluation yielded an average grade of $0.57 \mathrm{cpht}$. When viewed in retrospect, the mining history and reported diamond grades appear consistent with known geology and proposed erosion processes at work in the area.

\section{ECONOMIC CONSIDERATIONS}

The mining history and economic evaluation of the in-situ Prairie Creek lamproite vent proves that it has limited commercial economic potential even utilizing modern large-scale bulk mining equipment. The 1990's evaluation proved that although the total resource size is significant, the in-situ diamond grade is too low for economic consideration. However, a review of these results in conjunction with the sparse mining records suggests that early mining grades were significantly higher due to weathering and diamond concentration in the soil overburden.

The commercial alluvial potential of diamonds derived from the Prairie Creek lamproite vent can be determined utilizing this erosion model. Erosion estimates for this vent indicate that a maximum of 50 meters of erosion has occurred since the Cretaceous. Previous calculations have revealed that the pyroclastic lamproite eroded from the vent would have yielded approximately 93,000 carats of diamonds. Diamonds contained within the surface lag concentrations which were less than a meter thick and covered $\sim 16$ hectares of the intrusion would have yielded approximately 58,000 carats of diamonds. Of this amount of diamond, it is estimated that $\sim 29,000$ carats of the larger stones were recovered by early mining operations and another $\sim 29,000$ carats of the smaller stones were lost to the tailings.

Approximately 35,000 carats of diamonds could have been removed from the vent area. These diamonds would be contained in adjacent eluvial deposits and small erosion channels, and they would ultimately be delivered to the Little Missouri River for transport and fluvial concentration. Using the average value of diamonds recovered during the Phase 2 evaluation $(\$ 12.30$ per carat), the potential value of all the Prairie Creek intrusion alluvial diamonds is approximately US \$430,000. Obviously, commercial alluvial diamond deposits along the Little Missouri River are not economically feasible.

Approximately 35,000 carats of diamonds are estimated to have been removed from the surface and many are probably contained in eluvial deposits adjacent to the vent. These deposits adjacent to the intrusion may provide promising targets for further tourist development within the park.

Past diamond evaluation efforts have indicated that although all seven known vents are probably diamondiferous, their diamond grades are sub-economic. Minimal erosion of all known vents minimizes the alluvial potential of the region. However, the existence of widespread younger sedimentary cover permits the existence of as yet undiscovered diamond-bearing intrusions in the region.

\section{REFERENCES}

Dunn, D., 2002. Xenolith mineralogy and geology of the Prairie Creek lamproite province, Arkansas: Ph.D. dissertation, Univ. of Texas at Austin, Austin, TX, 147 pp.

Fuller, J., 1931. Reports and information gathered by John T. Fuller from 1908 to 1931, diamond fields in Pike County, Arkansas (unpublished), April 1931, 45 pp.

Gogineni, S.V., Melton, C.E. and Giardini, A.A., 1978. Some petrological aspects of the Prairie Creek diamondbearing kimberlite diatreme, Arkansas: Contributions to Mineralogy and Petrology, v. 66, p 251-261. 
Mitchell, R.H. and Bergman, S.C., 1991. Petrology of lamproites: New York, New York, Plenum Press, 447 pp.

Morgan Worldwide Mining Consultants, 1997. Crater of Diamonds State Park Evaluation Program, final report, Arkansas State Parks, Recreation and Travel Commission, Little Rock, Arkansas, 108 pp.

St. Clair, J., 1956. Report on the Arkansas Diamond Property (unpublished), Grand Junction, Colorado, August 14, 1956: $21 \mathrm{pp}$.

Thoenen, J.R., Hill, R.S., Howe, E.G. and Runkek, S.M., 1949. Investigation of the Prairie Creek Diamond Mine Area, Pike County, Arkansas: U.S. Bureau of Mines Report of Investigations 4549: 24pp.

Van Schmus, W.R., Bickford, M.E., Sims, P.K., Anderson, R.R., Shearer, C.K. and Treves, S.B., 1986. Proterozoic geology of the western midcontinent basement: geology of North America, v. c.2, p. 239-259.

Waldman, M.A., McCandless, T.E., and Dummett, H.T., 1987. Geology and petrography of the Twin Knobs \#1 lamproite, Pike County, Arkansas in Mantle Metasomatism and Alkaline Magmatism. Geological Society of America Special Paper \#215, p. 205-216.

Dennis P. Dunn

5802 Republic of Texas Blvd.

Austin, Texas 78735

dendunn@ix.netcom.com 